\title{
Functional Significance of Prop-1 Gene Expression in Pituitary Adenomas
}

\author{
TAKeshi USUI*,***, Yoshio NAKAMURA*, Haruo MIZUTA*, Hiroyuki MURABE*, Seiji MURO*, \\ Michio SUDA*, KIYoshi TANAKA*, Issei TANAKA*, AKIRA SHIMATSU** AND KazUwa NAKAO* \\ * Department of Medicine and Clinical Science, Kyoto University Graduate School of Medicine, Kyoto 606-8397, Japan \\ ${ }^{* *}$ Department of Laboratory Medicine, Kyoto University Graduate School of Medicine, Kyoto 606-8397, Japan \\ *** Clinical Research Institute, Kyoto National Hospital, Kyoto 612-8555, Japan
}

\begin{abstract}
Prophet of Pit-1 (Prop-1), which is a paired-like homeodomain transcription factor, is capable of binding to sites in an early enhancer of the Pit-1 gene and regulating its expression. As human Pit-1 is expressed considerably in pituitary adenomas, we studied human Prop-1 gene expression in pituitary adenomas. We also sequenced the Prop-1 cDNAs in pituitary adenomas. Human Prop-1 transcript was detected in all pituitary adenomas examined by RT-PCR analysis. The expression of human Prop-1 in pituitary adenomas was confirmed by in situ hybridization in one of the GH-producing adenomas. The sequence analysis of human Prop- 1 cDNAs in these pituitary adenomas revealed that there were no mutations except 5 silent nucleic acid substitutions, suggesting that mutations of Prop1 gene do not represent a frequent mechanism of human pituitary tumorigenesis.
\end{abstract}

Key words: Human Prop-1, Gene expression, Pituitary adenoma, Transcription, Direct sequencing

(Endocrine Journal 47: S85-S89, 2000)

THE molecular basis for dwarfism has been revealed to be the mutations of various genes. For example, Pit-1 has been shown to be responsible for the dwarf phenotype of Snell $(d w)$ and Jackson $(d w J)$ [1], GRF receptor for little mouse (lit/lit) [2], and Hmgi-c for pygmy ( $p g)$ [3], respectively. Recently, a positional cloning approach has identified a novel, paired-like homeodomain transcription factor, Prophet of Pit-1 (Prop-1), as responsible for a heritable form of murine pituitary-dependent dwarfism (Ames dwarf, df) [4]. Prop-1 is capable of binding to sites in an early enhancer of the Pit-1 gene [5] and regulating its expression. In the Ames mouse, a single amino acid substitution in the first helix of the Prop-1 homeodomain seems to result in the impairment of its DNA binding. Hypoplastic anterior pituitary gland in the Ames mouse with few somatotropes, lactotropes, or thyrotropes, appears to reflect a failure of determi-

Correspondence to: Dr. Takeshi USUI, Clinical Research Institute, Kyoto National Hospital, 1-1 Mukaihata-cho Fukakusa Fushimi-ku Kyoto 612-8555, Japan nation of the Pit-1 lineages from perilumental pituitary cells, suggesting that Prop-1 is essential to the asymmetric cell division that generates the Pit-1 lineages.

In this study, we investigated human Prop-1 expression in pituitary adenoma cells and we sequenced the Prop-1 cDNAs derived from pituitary tumors to determine the mutations that might have led or contributed to their tumorigenesis.

\section{Materials and Methods}

\section{$R T-P C R$}

14 Human pituitary adenoma tissues (5 GH-, 3 PRL-, 2 TSH-, 1 ACTH- producing, and 3 nonfunctioning adenomas) were obtained by transsphenoidal surgery. cDNAs were synthesized from these tumors, and RT-PCR was performed with sets of primers. The forward and reverse primers were as follows; S1 and A1 for human Prop-1, 5'-GGAAT- 
GAGGATCCAAGCTTTTACTTCGGCT- $3^{\prime}$ and $5^{\prime}$ GGTTCTGCAGATGACAGGAAGGAACAG-3' for human Pit-1, and 5'-CCGCGTCTCCTTTGAGCTGTTTGCAG- ${ }^{\prime}$ and $5^{\prime}$-ACCCAAAGGGAACTGCAGCGAGAGC-3' for human cyclophilin [10] as an internal control.

\section{In situ hybridization for human Prop-1}

One of the GH producing adenoma tissues obtained by transsphenoidal surgery (Case 5) was fixed, dehydrated, and embedded in paraffin. The sense and antisense probes for Prop-1 and GH were labeled with digoxigenin-dUTP which was obtained from an RNA labeling kit (Boehringer Mannheim, Germany).

\section{Sequencing of human Prop-1 expressed in pituita- ry adenomas}

To examine whether the Prop-1 gene could be an oncogene in human pituitary tumors, we amplified and directly sequenced the entire coding region of Prop-1. cDNAs derived from pituitary adenomas were amplified by PCR with $P f u$ DNA polynerase. The PCR products were collected from 1.5\% low melting agarose gel and purified by means of a QIAquick Gel Extraction Kit. The purified products were used for direct sequencing with a Dye Primer Cycle Sequence FS Ready Reaction Kit (-21M13) (Applied Biosystems, Warrington, U.K.). Sequenc- ing was performed with a 373A DNA Sequencer (Applied Biosystems).

\section{Results}

Expression of human Prop-1 in tumoral pituitary cells

By RT-PCR analysis, it was demonstrated that human Prop-1 mRNA was expressed in all of the 14 human pituitary adenomas examined. On the other hand, human Pit-1 mRNA was expressed in only GH-, PRL- and TSH-producing adenomas, but not in ACTH-producing and nonfunctioning adenomas (Fig. 1). Expression of human Prop-1 gene in pituitary adenomas was confirmed by in situ hybridization analysis in one of the GH-producing adenomas (Fig. 2a). Human Prop-1 mRNA was co-localized with GH mRNA in the nuclei of pituitary adenoma cells (Fig. 2a, b).

Sequence of human Prop-1 gene in pituitary adenomas

The nucleotide sequences of PCR products were identical to those of human Prop-1 cDNA, except for 5 silent mutations (amino acid 9, Ala, GCC for GCT; amino acid 56, Phe, TTT for TTC; amino acid 111, Ala, GCG for GCC; amino acid 112, Arg, AGA for

a

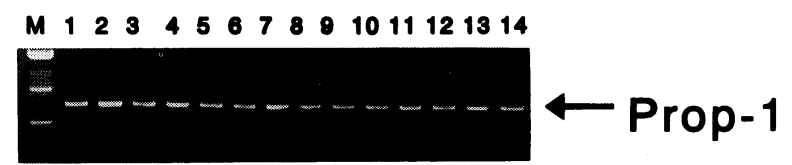

b

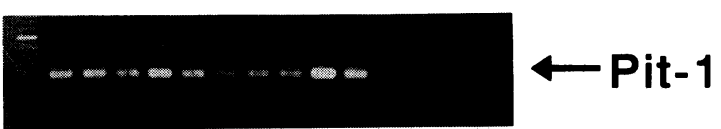

C
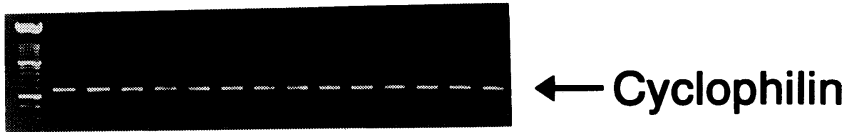

Fig. 1. RT-PCR of RNAs from pituitary adenomas with human Prop-1 (a), Pit-1 (b) and cyclophilin (c) primers. Lanes 1-5: GH-producing adenomas; lanes 6-8: PRL-producing adenomas; lanes 9-10: TSH-producing adenomas; lane 11: ACTH-producing adenoma; lanes 12-14; nonfunctioning adenomas. $M$ indicates a size marker of the $100 \mathrm{bp}$ DNA Ladder (New England Biolabs, Beverly, MA). None of the PCRs examined without reverse transcriptase yielded any bands (data not shown). 


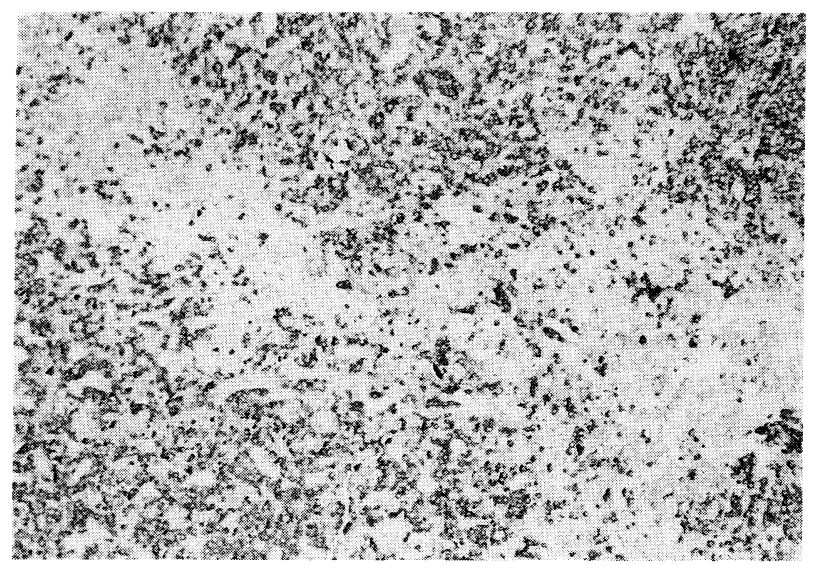

a

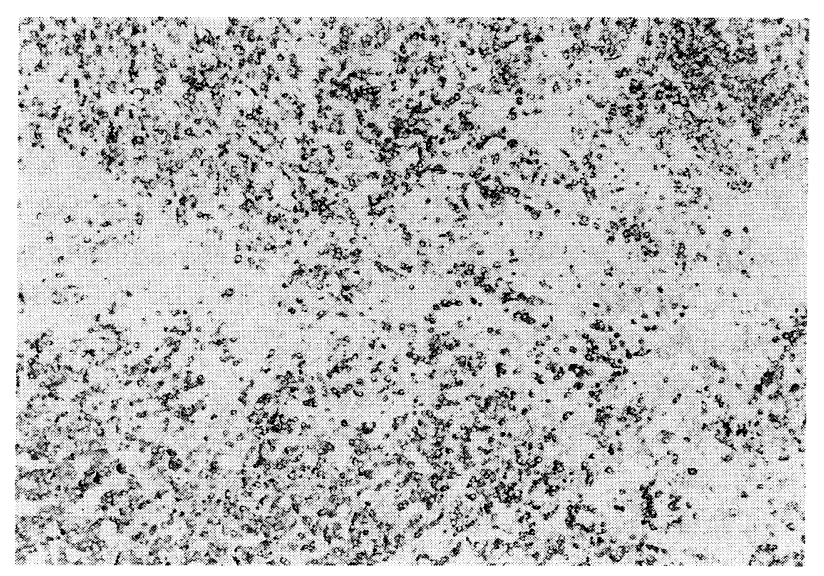

b

Fig. 2. In situ hybridization of paraffin sections of a GH-producing adenoma. (a) Positive hybridization signal is present in the nuclei of many tumor cells with Prop-1 antisense probe. The hybridization with the sense probe resulted in only a background signals (data not shown). (b) A positive hybridization signal with the GH antisense probe is present in the same cells in which the hybridization signal with the Prop-1 antisense probe exists. (a) and (b) are serial sections.

CGA; amino acid 203, Ala, GCG for GCC), which were all heterozygotes. Amino acid 142 was a homozygote of Thr in 8 cases and Ala in one case, and a heterozygote of Thr and Ala in 5 cases (Table 1).

\section{Discussion}

We examined human Prop-1 mRNA expression in pituitary adenomas by RT-PCR analysis. As shown in Fig. 1, Prop-1 mRNA was expressed in all the pituitary adenomas we examined, whereas Pit-1 mRNA expression was restricted to GH-, PRL- and TSH-producing adenomas. Previous reports on Pit1 mRNA expression have been controversial. Some investigators have reported that Pit-1 mRNA is expressed in pituitary adenomas other than GH-, PRLand TSH-producing adenomas [6-9], and others have reported that in most cases it is expressed only in

Table 1. Nucleic acid substitutions in human Prop-1 in pituitary adenomas

\begin{tabular}{|c|c|c|c|c|}
\hline Case No. & Tumor type & Immunohistochemistry & Mutations (wild to mutaut) & Condon 142 \\
\hline 1 & Somatotropinoma & GH & Condon 112 Arg (CGA to AGA) & GCC (Ala)/ACC (Thr) \\
\hline 2 & Somatotropinoma & GH & Condon 112 Arg (CGA to AGA) & ACC (Thr)/ACC (Thr) \\
\hline 3 & Somatotropinoma & GH & No mutation & ACC (Thr)/ACC (Thr) \\
\hline 4 & Somatotropinoma & GH & Condon 112 Arg (CGA to AGA) & ACC (Thr)/ACC (Thr) \\
\hline 5 & Somatotropinoma & GH & No mutation & GCC (Ala)/ACC (Thr) \\
\hline 6 & Lactotropinoma & PRL & $\begin{array}{l}\text { Condon } 56 \text { Phe (TCC to TTT) } \\
\text { Condon } 111 \text { Ala (GCC to GCG) } \\
\text { Condon } 112 \text { Arg (CGA to AGA) }\end{array}$ & ACC (Thr)/ACC (Thr) \\
\hline 7 & Lactotropinoma & PRL & No mutation & GCC (Ala)/GCC (Ala) \\
\hline 8 & Lactotropinoma & PRL & No mutation & GCC (Ala)/ACC (Thr) \\
\hline 9 & Thyrotropinoma & TSH, GH, PRL & Condon 112 Arg (CGA to AGA) & ACC (Thr)/ACC (Thr) \\
\hline 10 & Thyrotropinoma & TSH & Condon 9 Ala (GCT to GCC) & GCC (Ala)/ACC (Thr) \\
\hline \multirow[t]{2}{*}{11} & Corticotropinoma & $\mathrm{ACTH}$ & Condon 56 Phe (TTC to TTT) & \\
\hline & & & Condon 203 Ala (GCC to GCC) & ACC (Thr)/ACC (Thr) \\
\hline 12 & Nonfunctioning adenoma & Negative & No mutation & GCC (Ala)/ACC (Thr) \\
\hline 13 & Nonfunctioning adenoma & Negative & No mutation & ACC (Thr)/ACC (Thr) \\
\hline 14 & Nonfunctioning adenoma & Negative & No mutation & ACC (Thr)/ACC (Thr) \\
\hline
\end{tabular}


GH-, PRL- and TSH-producing adenomas $[10,11-$ 14]. The expression of Pit-1 in ACTH-producing and clinically nonfunctioning adenomas might be explained by the existence of tumor cells that are focally differentiated into Pit-1 lineage cells or trapped, intermingled normal pituitary cells in the adenomas [15]. No evidence of Pit-1 mRNA in ACTHproducing and clinically nonfunctioning adenoma cells in this study indicates that these tumor tissues were not contaminated with normal pituitary cells or tumor cells which have characteristics of Pit-1 lineage cells. Recently it has been reported that some patients who have human Prop-1 gene mutations have not only GH, PRL and TSH deficiencies but also have lower LH, FSH and ACTH levels in serum than normal subjects $[16,17,18]$, which are not observed in patients who have Pit-1 gene mutations. Therefore, the expression of Prop-1 gene in ACTHproducing and clinically nonfunctioning adenomas, many of which are reported to secrete gonadotropin subunits [19], suggests that human Prop-1 might have functions other than as a Pit-1 gene enhancer, such as regulating cell division which is independent of Pit-1 lineage directly or regulating pituitary specific transcription factor(s) other than Pit-1.

No mutations except 5 silent nucleic acid changes were found in human Prop-1 cDNA in GH-, PRL-, TSH- and ACTH-producing pituitary adenomas, suggesting that abnormalities of the Prop-1 gene might not be frequent mechanisms of human pituitary tumorigenesis. Further studies are required to elucidate its relation to the pathogenesis of pituitary adenomas.

\section{Acknowledgements}

We thank Ms. Keiko Matsuda for her excellent technical assistance. This work was supported in part by research grants from the Naito Foundation; the Uehara Memorial Foundation and the Japanese Society for the Promotion of Science "Research for the Future” program (JSPS-RFTF 96100204).

\section{References}

1. Li S, CrenshawIII EB, Rawson EJ, Simmons DM, Swanson LW, Rosenfeld MG (1990) Dwarf locus mutants lacking three pituitary cell types results from mutations in the POU-domain gene pit-1. Nature 347: 528-533.

2. Lin S-C, Lin CR, Gukovsky I, Lusis AJ, Sawchenko PE, Rosenfeld MG (1995) Molecular basis of the little mouse phenotype and implications for cell typespecific growth. Nature 364: 208-213.

3. Zhou X, Benson KF, Ashar HR, Chada K (1995) Mutation responsible for the mouse pygmy phenotype in the developmentally regulated factor HMGI-C. Nature 376: 771-774.

4. Sornson MW, Wu W, Dansen JS, et al. (1996) Pituitary lineage determination by the Prophet of Pit-1 homeodomain factor defective in Ames dwarfism. Nature 384: 327-333.

5. DiMattia GE, Rhodes SJ, Krones A, et al. (1997) The Pit-1 gene is regulated by distinct early and late pituitary-specific enhancers. Dev Biol 182: 180-190.

6. Sanno N, Teramoto A, Matsuno A, Osamura Y (1996) Expression of human Pit-1 product in the human pituitary and pituitary adenomas. Arch Pathol Lab Med 120: 73-77.

7. Lloyd RV, Jin L, Chandler WF, Horvath E, Stefaneanu L, Kovacs K (1993) Pituitary specific transcription factor messenger ribonucleic expression in adenomatous and nontumorous human pituitary tissues. Lab Invest 69: 570-575.

8. Hoggard N, Callaghan K, Levy A, Davis JRE (1993) Expression of Pit-1 and related proteins in diverse human pituitary adenomas. J Mol Endocrinol 11: 283-290.

9. Hamada K, Nishi T, Kuratsu J, Ushio Y (1996) Expression and alternative splicing of Pit-1 messenger ribonucleic acid in pituitary adenomas. Neurosurgery 38: 362-366.

10. Pellegrini I, Barlier A, Gunz G, et al. (1994) Pit-1 gene expression in the human pituitary and pituitary adenomas. J Clin Endocrinol Metab 79: 189-196.

11. Friend KE, Chiou Y-K, Laws ER, Lopes MB, Shupnik MA (1993) Pit-1 messenger ribonucleic acid is differentially expressed in human pituitary adenomas. J Clin Endocrinol Metab 77: 1281-1286.

12. Inada $\mathrm{K}$, Oda $\mathrm{K}$, Utsunomiya $\mathrm{H}$, et al. (1993) Immunohistochemical expression of Pit-1 protein in human pituitary and pituitary adenomas. Endocr Pathol 4: 201-204.

13. Asa SL, Puy LA, Lew AM, Sundmark VC, Elsholtz HP (1993) Cell type-specific expression of the pituitary transcription activator Pit-1 in the human pituitary and pituitary adenomas. $J$ Clin Endocrinol 
Metab 77: 1275-1280.

14. Delhase M, Vergani P, Malur A, et al. (1993) Pit1/GHF-1 expression in pituitary adenomas: further analogy between human adenomas and rat SMtTW tumors. J Mol Endocrinol 11: 129-139.

15. Yamada S, Takahashi M, Hara M, et al. (1996) Pit-1 gene expression in human pituitary adenomas using the reverse transcription polymerase chain reaction method. Clin Endocrinol 45: 263-272.

16. Wu W, Cogan JD, Pfaffle RW, et al. (1998) Mutations in PROP1 cause familial combined pituitary hormone deficiency. Nature Genet 18: 147-149.

17. Parks JS, Brown MR, Baumbach L, et al. (1998) Natural history and molecular mechanisms of hypo- pituitarism with large sella turcica. Program of the 80th Annual Meeting of The Endocrine Society, New Orleans, LA (Abstract P3-409).

18. Brown MR, Lenartowska I, Oltarzewski M, Wu W, Rosenfeld MG (1998) Pro-1 mutations and hypopituitarism in Poland. Program of the 80th Annual Meeting of The Endocrine Society, New Orleans, LA (Abstract P3-413).

19. Sanno N, Teramoto A, Sugiyama M, Itoh $\mathrm{Y}$, Osamura RY (1996) Application of catalyzed signal amplification in immunodetection of gonadotropin subunits in clinically nonfunctioning pituitary adenomas. Am J Clin Pathol 106: 16-21. 